\title{
Effect of Regulation on Outreach of Microfinance Institutions in Ghana
}

\author{
Joyce Ama Quartey (Corresponding author) \\ Department of Accounting and Finance \\ PO Box 3110 Kumasi, Ghana
}

Tel: 233-244-733-807Ｅ-mail: jquartey@csuc.edu.gh

\author{
Bernice Kotey \\ UNE Business School, University of New England, Armidale, Australia
}

Received: January24, 2019 Accepted: February 21, 2019 Published: February 24, 2019

doi:10.5296/ijafr.v9i1.14405

URL: https://doi.org/10.5296/ijafr.v9i1.14405

\begin{abstract}
Microfinance institutions (MFIs) play an important role in enhancing the growth potential of small businesses. However, while regulation ensures that MFIs are financially sustainable, compliance compels them to make large-sized loans to wealthy clients in order to reduce the risk of lending and minimize administrative costs, a situation that compromises their main goal of reaching out to the poor. The study therefore, examined the effect of regulation on breadth and depth of outreach by microfinance institutions (MFIs) in Ghana. The purpose of the study is to find out whether regulation has enabled MFIs to increase their outreach (breadth and depth) thereby improving their sustainability. A mixed methods research design was employed, involving initial hypotheses testing with 31 self-regulated and 24 Central bank-regulated MFIs. The findings were then triangulated with a qualitative research design involving 13 Central bank-regulated and 20 self-regulated MFIs. The results showed that regulations increased the client base of MFIs but reduced the percentage of poor clients served, largely women. It is recommended that the government set up a fund for poor clients to be accessed by well-performing MFIs for provision of financial services to the poor to assist in poverty reduction.
\end{abstract}

Keywords: Microfinance institutions, Breadth of outreach, Depth of outreach, Regulations, Ghana 


\section{Introduction}

Microfinance institutions (MFIs) have emerged to provide financial services to the poor who were hitherto, excluded from the formal financial system. In pursuit of this goal, the performance of MFIs is in part assessed by the number of poor clients served, although for MFIs to expand their reach to the poor, their businesses should be conducted on sound operating principles. This requires that MFIs comply with appropriate financial regulations to safeguard the deposits of their customers and ensure stability of the entire financial system (Christen, Lyman and Rosenberg, 2003; Arun, 2005; Llewellyn, 1999).

Up until 2011, MFIs in Ghana were regulated by various bodies. The rural and community banks (RCBs) and savings and loan companies (S\&Ls), regulated by the Bank of Ghana (BoG), had the most rigorous compliance requirements ensuring effective governance structures. In contrast, microfinance companies and "susu" operators, regulated by the Ghana Co-operative Susu Collectors Association (GCSCA), as well as money lenders licensed by the police under the Money Lenders Ordinance (1957) had the least compliance requirements and the most weak governance structures, a situation that prevented them from mobilizing voluntary savings for on-lending to their poor clients.

This study seeks to investigate the effect of regulation on outreach of MFIs in promoting small business growth. Small businesses provide a means of income generation for a large segment of the poor, many of who do not have the qualifications and experiences to be employed in positions that generate sufficient income to meet their needs. MFIs that operate under two different types of regulations are examined; the formal RCBs with the most compliance requirements and informal "susu" companies with the least regulatory requirements.

While regulation ensures that MFIs are financially sustainable, compliance compels them to make large-sized loans to wealthy clients in order to reduce the risk of lending and minimize administrative costs, a situation that compromises their main goal of reaching out to the poor. On the other end, regulations enable formal MFIs to mobilize voluntary savings from the public for on-lending to clients, an opportunity not available to informal MFIs. The impact of regulation on the ability of MFIs to serve the poor is an important area of study if MFIs are to remain financially sustainable as well as play a role in poverty alleviation. While studies on regulation abound in other countries, studies of this nature are lacking in Sub-Saharan Africa in general and for Ghana in particular, hence the need to investigate the effect of regulation on the outreach of MFIs in Ghana. The study is guided by the following research questions: What is the influence of regulation on the number of active clients (breadth of outreach), the average loan size (depth of outreach), and the percentage of female clients (depth of outreach)?

The remainder of this article is organized into four sections. The first argues the case for and consequences of regulating MFIs and generates hypotheses for testing. The research methodology is presented in the second section and the findings reported in the third. The article ends with a discussion and conclusion section where implications for policy and practice are provided. 


\section{Literature Review and Hypotheses Development}

A major goal of MFIs is to meet the financial needs of un-served or under-served markets in society and ultimately help to reduce poverty. Access to finance for small businesses not served by the main financial institutions would enable them to grow, diversify their activities, and create employment. Successful businesses in turn would empower women or other disadvantaged groups and encourage further entrepreneurial activities (Ledgerwood, 1999).

Llewellyn (1986, p. 9) defines regulation as "a body of specific rules or agreed behaviour, either imposed by some government or other external agency or self-imposed by explicit or implicit agreement within the industry, that limits the activities and business operations of financial institutions." Externally- or self- imposed regulations therefore alter the behaviour of market participants. Christen et al (2003, p. 7) differentiate between prudential and non-prudential regulations, explaining that regulation is prudential when it is aimed specifically at protecting the whole financial system as well as the safety of small deposits in individual institutions. Non-prudential regulation relates to how financial institutions conduct business with their customers (Llewellyn, 1999) and concerns issues such as consumer protection, information disclosure, prevention of fraud and financial crimes, and fair business practices (Christen et al, 2003). While a public and specialized supervisory body is often responsible for oversight of prudential regulation, non-prudential regulation could be self-imposed or controlled by any other authority (Christen et al, 2003; Llewellyn, 1999).

Microfinance institutions can be grouped into formal, semi-formal and informal providers with respect to the extent of their regulation. Formal MFIs are subject to both prudential and non-prudential banking regulations and supervision while semi-formal and informal MFIs are registered entities, subject to non-prudential regulations from their industry bodies. The categorization of MFIs into formal, semi-formal and informal institutions depends on the countries in which they operate. For instance, while credit unions may fall under semi-formal in one country, they may be informal in another. MFIs in each of the categories are described below as they applied in Ghana before the government's prudential regulations for all MFIs.

\subsection{Formal MFIs}

Formal MFIs in Ghana include the RCBs and the S\&Ls which operate within the same compliance structures before the reforms. The RCBs are unit banks owned by members of a rural community and regulated by the Bank of Ghana (BoG) under the Banking Law 1989 (PNDCL, 225), they are therefore part of the regulated financial sector (GHAMFIN, 2008). The RCBs are the largest microfinance providers in the rural areas and represent about half of the total banking outlets in Ghana (IFAD, 2008). They were established to expand savings mobilization and credit services to rural areas not served by the commercial and development banks. The need to promote and strengthen the rural banking concept led to establishment of the Association of Rural Banks' (ARB) Apex Bank in 1981 as a licensed banking institution under the Banking law. Owned exclusively by the RCBs, the ARB Apex Bank is responsible for providing check clearing, liquidity management, capacity building, computerization and other non-prudential controls and services for member RCBs (Steel and Andah, 2003; Boapeah, 2011). Most of the RCBs provide individual and group loans to their clients (Chord, 
2000) and have introduced innovative programmes to reach poor clients.

Established in 1990, S\&Ls are deposit-taking financial institutions regulated by BoG under the Non-Bank Financial Institution (NBFI) law 1993 (PNDCL 328). The S\&Ls normally operate in the urban and peri-urban areas of Ghana, serving mostly the economic-active but unbanked population and providing tailored products to meet their needs (Quaye and Sarbah, 2014). S\&Ls provide: credit to low income clients and small businesses, money transfer services, training in financial literacy, and deposit mobilization. They specialize in individual rather than group loans.

The prudential standards imposed by the BoG on the above two formal MFIs consist of minimum capital requirements and capital adequacy levels, asset quality standards, limits on risk exposure, and liquidity management guidelines. In regulating these MFIs, the BoG exercises its mandate to ensure that depositors' funds are safe and that the solvency, good quality assets, adequate liquidity and profitability of these MFIs are maintained (BoG, 2011).

\subsection{Semi-Formal MFIs}

Institutions operating in the semi-formal sphere include credit unions and cooperatives, financial non-governmental organizations (FNGOs) and village banking. Bouman (1995) and Rutherford (2000) referred to credit unions (CUs) as accumulating savings and credit associations (ASCA) because they gather funds from community members and channel them to investors in a lump sum. All members, savers and borrowers are shareholders of the credit union (Robinson 2001). Key decisions about interest rates, maximum loan size, and changes to the constitutional chart of the credit cooperative are taken democratically by all members on a one-share-one vote basis. Credit unions grow their funds over time by disbursing loans that are repaid at regular intervals (Bouman, 1990). The size of loans can vary with the needs of their clients (Armendariz de Aghion and Morduch, 2005).

Credit unions are regulated by the Co-operative Decree, 1968 (NLCD 252) and registered by the Department of Cooperatives and the Credit Union Association (CUA), which serves as their self-regulation apex body. CUA applies prudential norms that are supported by the Canadian Cooperative Association (CCA), similar to the operating and financial standards of the World Council of Credit Unions (WOCCU) (Gallardo, 2002). Regulations include minimum membership, compulsory initial training of executive officers, minimum entrance and savings fees for members, and minimum accumulated savings for the credit union. Each registered credit union must transfer 25 per-cent of its annual declared profit to the CUA for investment. These requirements must be met as a condition for full registration of a new credit union. Supervisory and monitoring are carried out by managers at the regional level who supervise individual credit unions at the district and local levels. The supervisors ensure that rules and regulations are adhered to, prudent financial practices are adopted, and accounts prepared regularly and audited (CUA, 2012).

Financial Non-Governmental Organizations (FNGOs) combine provision of microfinance services with social services such as education and health (Dunford, 2001). Bhatt and Tang (2001, p. 321) provide three reasons why FNGOs have widespread appeal as microfinance 
delivery vehicles among donors, technical co-operation agencies and consumers. First, FNGOs demonstrate concern for their constituencies by their close association with civil society. Second, some FNGOs provide the poor with non-financial services such as training and technical assistance in areas of adult literacy, health and business practices. These non-financial services enhance the socio-political position of the poor, especially women. Third FNGOs, recognized as operating on the principles of "trust, generosity and ideology", are considered more reliable as agents for serving the poor than both government and private sector organizations. Bhatt and Tang (2001) conclude that because FNGOs adopt formal management practices, attend to efficiency of operations, and develop innovative saving/credit delivery practices, they have made significant improvements in the lives of the poor. FNGOs are well known for adopting internationally-tested microfinance products often for groups of clients.

FNGO's are charitable institutions and comply with the regulations for Trust and Charitable Institutions. In Ghana, they are incorporated as companies limited by guarantee (not-for-profit) under the Companies Code 1963 (Act 179). The Association of FNGOs (ASSFIN) was inaugurated in 2005 as an apex organization of all FNGOs in Ghana with the aims of regulating the activities of member institutions and advocating for their development (Ghana Microfinance, n.d; Adjei, 2010).

The village banking model of financial service delivery was developed by the Foundation for International Community Assistance (FINCA) and used by a range of FNGOs in a number of countries (Johnson and Rogaly, 1996) such as El Salvador, Thailand, Burkina Faso, Ghana and Benin (Ledgerwood, 1999). Village banking is therefore subject to a similar regulatory framework as the FNGOs, although the responsibility of running the bank's activities including the entire management of loans (distribution, collection of repayment, repayment, book keeping) falls on clients as members (Dunford, 2001). Members normally go through an initial period of training where they learn the rules of village banking and how to manage their own village bank (Dunford 2001). Clients of village banks are usually from rural or sparsely populated, but sufficiently cohesive areas. They generally have very low incomes but have saving capacity, and are predominantly women (Ledgerwood, 1999).

\subsection{Informal MFIs}

Informal microfinance providers include rotating savings and credit associations (ROSCAs), "susu" companies, "susu" collectors and money lenders. ROSCAs are nearly universal and have simple structures usually comprising a group of individuals who agree to regularly contribute money to a common "pot" and to allocate the total contributions for each period to one member of the group (Armendariz de Aghion and Morduch, 2005). Recipients of each month's total contributions are rotated until every member is allocated the period's contributions (Armendariz de Aghion and Morduch, 2005). ROSCAs therefore successfully mobilize surplus funds that come into households into a large chunk that can be used to fund a major purchase. ROSCAs make it possible for the poor to access commercial credit (Todaro and Smith, 2003) and engage in any micro-business of their choice or cater for consumption or emergency needs. For people on low-incomes, ROSCAs can permit secure savings and 
facilitate regular savings habits (Armendariz de Aghion and Morduch, 2005). While ROSCA members are all both savers and borrowers, ROSCAs are vulnerable to failure if their managers are corrupt, members lack discipline or when a collective shock occurs (Robinson, 2001) ROSCAs are carried out informally and not regulated.

"Susu" companies operate as registered businesses under the Ghana Co-operative Susu Collectors Association (GCSCA) which requires a minimum capital of 60,000 Ghana cedis for commencement (GHAMFIN, 2008). Susu companies are not allowed to accept voluntary savings but they use compulsory savings as cash collateral for loans. Clients are expected to save daily for a minimum of six months before they can qualify for a loan (typically twice the amount saved) (Steel and Andah, 2003). The minimum capital and the compulsory savings enable susu companies to lend to clients who meet the minimum savings requirement. The interest on the loans becomes income to the company. Clients who pay off their loans and interest, can access their compulsory savings.

"Susu" collectors collect daily amounts set by each of their clients, usually traders and artisans, and return the accumulated amount at the end of the month, minus one day's amount as a commission (GHAMFIN, 2008). "Susu" collectors are the most visible form of providers of microfinance services in Ghana and constitute an important form of savings (Adjei, 2010). Licensed financial institutions such as commercial banks, RCBs, S\&Ls, CUs and FNGOs have introduced savings products similar to "susu" and use salaried or commissioned agents for the daily collections (Steel and Andah, 2003). However, many "susu" collectors remain unregistered and operate on trust basis with their clients. Though income obtained from "susu" is normally spent on consumer goods, many customers use it as a source of capital to start or expand their businesses (Aryeetey, 1995; Alabi et al, 2007).

Established in 1994, the Ghana Co-operative "Susu" Collectors Association (GCSCA) is registered under Paragraph 4-7 of the Co-operative Society Law (NLC Decree 252) 1968 and affiliated to the Ghana Cooperative Council. It is an umbrella organization for all regional "susu" collectors and "susu companies" in Ghana and a self-regulatory body (GCSCA, 2007, p. 2).Under the GCSCA, a prospective member must meet certain criteria for admission to the association and for operating as a "susu" collector or "susu" company. The prospective member must be recommended by a zonal executive, submit a written application, provide two sworn guarantors, deposit 1 million Ghana cedis (about US\$250,000) into a security fund, meet the minimum capital requirements, and save 5,000 Ghana cedis a month. The security fund serves as a reserve to protect depositors' funds. Prospective members must also take a medical examination and undergo three months training with an existing member. The GCSCA performs its supervising and monitoring role through regular field monitoring of operations of registered members at the local level. The GCSCA has zonal and district teams responsible for auditing the books of registered members (GCSCA, 2007). It must be noted that despite the self-regulations, many "susu" collectors and "susu" companies are informal and unregistered.

Money lenders are also informal providers of microfinance. They are an important source of emergency and short-term finance for a large percentage of the population lacking access to 
commercial financing (IFAD, 2000; Steel and Andah, 2003). Money lenders are usually wealthy farmers or traders who have either their own funds to lend or access to credit from banks. They normally lend money at exorbitant interest rates for weddings, funerals, urgent medical expenses, purchase of extra food, or for more productive activities in farming or off-farm activities. They are licensed by the police under the Money Lenders Ordinance (1957) but generally operate informally.

With the proliferation of MFIs in Ghana, the need to ensure financial system stability and to safeguard the deposits of their customers (Christen, Lyman and Rosenberg, 2003; Arun, 2005) became pressing, prompting the Central Bank to initiate a process of regulating the activities of all MFIs. In 2011, the government imposed a set of prudential regulations on each of the self-regulated (semi-formal and informal) MFIs, in addition to their existing non-prudential regulations. Nonetheless, the RCBs and S\&Ls still face more rigorous regulations than the self-regulated MFIs, with the previously informal MFIs facing the least stringent regulations. However, MFIs were reorganised into four tiers with respect to compliance requirements and "susu" companies were elevated to tier 2. The quantitative data for this study were collected before the government's regulation when "susu" companies were classified as informal with the least regulatory requirements compared with the RCBs which had the most compliance requirements. At the time of collecting the qualitative data the Central Bank had started implementing prudential regulations for the self-regulated MFIs, including "susu" companies.

\subsection{Outreach}

Outreach is the ability of an MFI to provide high quality financial services to a large number of clients (Congo, 2002). The concept of outreach is multi-dimensional and involves several indicators including: breadth of outreach (number of clients served), depth of outreach (the value that society attaches to the net gain of a given client), cost of outreach (the price of outreach and transaction costs), worth of outreach to clients (their willingness to pay), length of outreach (the time frame of the supply of microfinance) and scope of outreach (number of types of financial contracts supplied) (Schreiner, 2002; Navajas, 2000). Schreiner (2002) notes that many of these indicators are difficult to measure so that the majority of studies examine breadth and depth of outreach (Hartarska 2005; Cull et al 2007; Hermes et al 2011; Kar 2011; Ferro Luzzi and Weber 2006). Breadth of outreach is measured by the number of active borrowers of an MFI (Koveos and Randhawa, 2004; Schreiner, 2002; Kar, 2011) or number of active clients (Rosenberg 2009; Kereta, 2007). The higher that the number of active clients or borrowers, the more extensive the breadth of outreach. Nonetheless, extensive outreach does not provide an indication of reaching the poor since the MFI may be serving wealthy clients with high repayment potential. To reach the poor an MFI must also demonstrate reasonable depth of outreach.

It is argued that people with less income and assets will demand small-sized loans (Gonzalez and Rosenberg, 2006). Therefore, very small average loan sizes provide an indication that an MFI is reaching the very poor. The average loan size is usually taken as a proxy for the depth of outreach. The percentage of female borrowers is another measure of depth of outreach (Hermes et al, 2011; Weber, 2006; Hassan, Hasan, and Uddin, 2009). Women in developing 


\section{$\triangle$ Macrothink}

International Journal of Accounting and Financial Reporting

ISSN 2162-3082

2019, Vol. 9, No. 1

countries are perceived as poorer than men and less autonomous at any given level of wealth or income (De Crombrugghe, Tenikue and Sureda, 2008). Therefore, the higher the percentage of women served by a MFI, the greater the depth of outreach. These measures of outreach help to differentiate between institutions serving the poorest clients and those that serve wealthy clients (Cull et al, 2011). Depth and breadth of outreach are examined in this study as indicators of outreach.

\section{Conceptual Framework and Hypotheses Development}

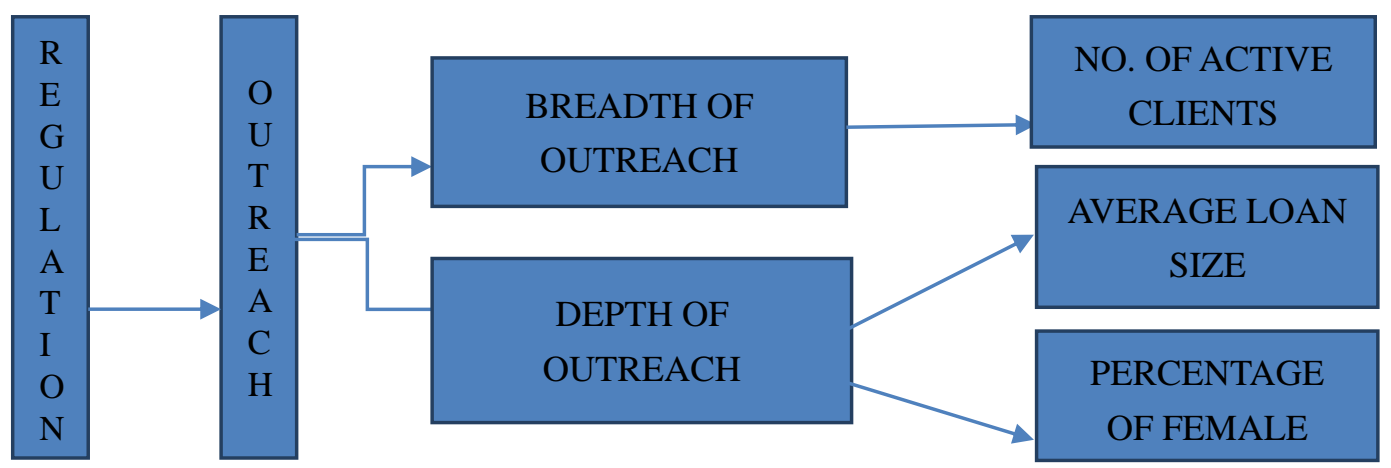

Figure 1. Conceptual framework on effect of regulation on outreach of MFIs

The outreach of the MFIs was measured by using the breadth of outreach, proxied by the number of active clients and depth of outreach, proxied by the average loan size and the percentage of female clients. The study was interested in investigating the influence of regulation on the outreach of MFIs.

Prior to the government's regulations, the formal MFIs were able to grow their loan portfolios from mobilized savings for on-lending to clients (Fiebig, Hannig and Wisniwski, 1999), enabling them to reduce their dependence on donors. Saving mobilization helped these MFIs to adhere to strict financial discipline and ultimately improve their operational efficiency. Since the formal MFIs were able to increase funds available for lending from mobilized savings (Wisniwski, 1999; Robinson, 2001; Otto and Ashta, 2012), they should have been able to reach out to more clients than the informal MFIs. However, complying with regulations and its associated supervision can be costly (Cull et al, 2011). Staschen (2010, cited in Nyanzu and Peprah, 2016) also observed that regulation can be associated with additional cost to the MFIs, which may eventually result in the marginalization of the poor. In view of this, it is argued that regulatory involvement may lead to a "mission drift," from serving poor to wealthy clients (Hartarska and Nadolnyak, 2007).

Paxton and Cuevas (2002) suggest that since informal MFIs have deeper outreach, they are able to serve the poorer segments of the society better than the formal MFIs. The results from a study by Cull et al (2011) also showed a positive relationship between supervision and loan size, implying that the higher the prudential supervision, the larger the loan size and the less deep the outreach. Consequently, formal MFIs would have greater breadth of outreach but less depth of outreach than informal MFIs because regulation allows the former access to voluntary deposits from the public as well as private sector capital, increasing their loanable funds. However, formal MFIs would be inclined to target few poor clients to ensure full 
repayment of their loans. Furthermore, there are economies of scale to regulatory costs, so that formal MFIs are likely to face higher average cost than the commercial financial institutions (Elliehausen and Kurtz, 1988 cited in Cull et al, 2011). Therefore, formal MFIs would target wealthy clients to improve their ability to absorb regulatory costs. In view of the above positions, the following hypotheses are developed for testing:

- Hypothesis 1

Null Hypothesis $1\left(\mathrm{H}_{0}\right)$ : Regulation is not associated with breadth of outreach for MFIs

Alternative hypothesis $1\left(\mathrm{H}_{1}\right)$ : Regulation is positively associated with breadth of outreach for MFIs

- Hypothesis $2 \mathrm{a}$

Null Hypothesis $\left(\mathrm{H}_{0}\right)$ : Regulation is not associated with average loan size (less depth of outreach) for MFIs

Alternative hypothesis $\left(\mathrm{H}_{1}\right)$ : Regulation is positively associated with average loan size (less depth of outreach) for MFIs

- Hypothesis $2 b$

Null Hypothesis $2 \mathrm{~b}\left(\mathrm{H}_{0}\right)$ : Regulation is not associated with percentage of female clients (less depth of outreach) for MFIs

Alternative hypothesis $2 \mathrm{~b}\left(\mathrm{H}_{1}\right)$ : Regulation is negatively associated with percentage of female clients (less depth of outreach) for MFIs

\section{Research Methodology}

The study focused on the effect of regulation on the outreach of MFIs in Ghana. Research design consists of a set of methods and procedures employed in collecting and analyzing the measures of the variables stated in a research problem. This study adopted a descriptive research design and employed a mixed research method to address the research questions and research objectives.

The mixed research method covered two phases of the research process. The first phase, involving the use of the quantitative method, used survey questionnaire to examine the influence of regulation on the outreach of MFIs. The survey questionnaire was administered in face-to-face interviews to 55 MFIs (24 RCBs and 31 "susu" companies). They were randomly selected from the list of members from their parent bodies. The questionnaire used was first piloted using a convenient sample of six MFIs. The piloted questionnaire revealed the need to rephrase some of the questions to ensure better understanding. This was done and the questionnaire was reformatted before administering it.

The second phase of the study adopted a qualitative method by organizing in-depth interviews with the managers of 33 MFIs (13 RCBs and 20 "susu" companies). They were purposively selected and different from those surveyed for the quantitative study. Findings from the qualitative study were used to triangulate those from the quantitative study. The aim 
was to provide a more comprehensive understanding of the effect of regulation on the outreach of MFIs than could be obtained using only the quantitative approach.

Breadth of outreach was measured by number of active clients (NOAC) while average loan size (ALS) and percentage of women clients (PWC) were used as indicators of depth of outreach. Regulation was a dichotomous variable with RCBs rated 1 and the "susu" companies rated 2.

Factors such as the products and services provided by MFIs, their sizes and ages affect their outreach and were therefore controlled in testing the hypotheses. Some researchers argue that the provision of both financial and non-financial services would have greater impact on the businesses of MFI clients than financial services alone (Bhatt and Tang, 2001; Maes and Foose, 2006). The majority of MFIs in Ghana provide only financial services, a situation likely to increase breadth of outreach since these MFIs do not incur the additional costs of providing non-financial services.

The size of a MFI measured by total assets could also have a bearing on their outreach (Kar, 2011). A study by Hartarska and Nadolnyak (2007) showed that MFIs with bigger endowments would be efficient and able to attract additional capital from investors, enabling greater breadth of outreach. The control variables, age and size were converted to logarithm values while the original values for number of products were used in the analyses.

The study used the hierarchical regression to analyze the quantitative data on the effect of regulation (the independent variable) on breadth and depth of outreach, (the dependent variables). The use of hierarchical regression models have been recommended by researchers such as Richter (2006). Theoretically, hierarchical regression models produce appropriate error terms that control for potential dependency as a result of nesting effect (Newman, Newman and Salzman, 2010). Also hierarchical regression models enable several variances to be considered simultaneously (Richter, 2006). SPSS (20 version) was employed to analyze the quantitative data.

Deductive thematic analysis was also used to analyze the qualitative data. The method involved constructing themes and sub-themes identified from thorough reading and coding of transcripts of the interviews (Bryman, 2008). The themes were shaped by the literature review and ensuing questions (Saunders et al, 2007, p. 491). It enables data to be organized and described in rich details (Braun and Clarke, 2006). Thematic analysis was the preferred analytical method for the qualitative data collected through individual interviews because of its flexibility, and systematic and visible approach. It also enables in-depth examination of data to generate useful insight (themes) into the reality or experiences of individuals. The method analyses qualitative data efficiently because it draws from established theoretical framework and concepts (Yukhymenko et al, 2014).

\section{Results}

The results from the quantitative study are reported first followed by those from the qualitative analysis. The regression models formulated to test the hypotheses were as follows: 


\section{1l Macrothink}

International Journal of Accounting and Financial Reporting

ISSN 2162-3082 2019, Vol. 9, No. 1

H1 - Regulation is positively associated with breadth of outreach for MFIs

$$
\ln \left(\mathrm{NOAC}_{\mathrm{i}}\right)=\beta_{0}+\beta_{1} \ln \left(\text { Age }_{\mathrm{i}}\right)+\beta_{2} \ln \left(\text { Size }_{\mathrm{i}}\right)+\beta_{3} \text { Product }_{\mathrm{i}}+\beta_{4} \text { Regulation }_{\mathrm{i}}+\varepsilon_{\mathrm{i}}
$$

$\mathrm{H} 2 \mathrm{a}$-Regulation is positively associated with average loan size (depth of outreach) for MFIs

$$
\ln \left(\mathrm{ALS}_{\mathrm{i}}\right)=\beta_{0}+\beta_{1} \ln \left(\text { Age }_{\mathrm{i}}\right)+\beta_{2} \ln \left(\text { Size }_{\mathrm{i}}\right)+\beta_{3} \text { Product }_{\mathrm{i}}+\beta_{4} \text { Regulation }_{\mathrm{i}}+\varepsilon_{\mathrm{i}} \text { (2a) }
$$

$\mathrm{H} 2 \mathrm{~b}$ - Regulation is negatively associated with percentage of female clients (depth of outreach) of MFIs

$$
\ln \left(\mathrm{PWC}_{\mathrm{i}}\right)=\beta_{0}+\beta_{1} \ln \left(\text { Age }_{\mathrm{i}}\right)+\beta_{2} \ln \left(\text { Size }_{\mathrm{i}}\right)+\beta_{3} \text { Product }_{\mathrm{i}}+\beta_{4} \text { Regulation } \varepsilon_{\mathrm{i}}
$$

Where:

NOACi $=[$ Number of Active Clients $]$ Number of active borrowers and savers of the MFI.

ALS $=[$ Average Loan Size $]$ Average amount of loans to clients, measured depth of outreach.

PWC $=[$ Percentage of Women clients $]$ measured the depth of outreach

Age $=[$ Firm Age $]$ Firm age since incorporation

Size $=[$ Size of the firm $]$ sum of total assets in dollars of the firm

Product $=$ [Product provided by the MFI 1 for MFIs providing only financial services and 2 for MFIs providing both financial and non-financial services

$\beta_{0}=$ Intercept

$\varepsilon i=$ Error term

$\beta=$ Estimated slope coefficient of each variable

Age, size and product were control variables.

\subsection{ResultsFrom the Quantitative Study}

In testing the hypotheses the variance inflating factor (VIF) for all independent variables were estimated to assess multicollinearity. The results are shown in Table 1 . The maximum VIF recommended in literature are 4 by Pan and Jackson (2008), 5 by Rogerson (2001) and 10 by Hair, Anderson, Tetham and Black (1995). The VIFs for all the variables were less than 4 , therefore multicollinearity was minimal. The Breuch-Pegan test of heteroscedasticity was used for variables in hypothesis 1 . The null hypothesis that the variance of the error terms was constant against the alternative of unequal variance was examined. From the results, the null hypothesis was rejected indicating heteroscedasticity. To correct for this, the White robust standard error was used in the hierarchical regression analysis (White 1980).

Table 1. Diagnostic results for multicollinearity and heteroscedasticity tests 


\section{MlMacrothink}

International Journal of Accounting and Financial Reporting

\begin{tabular}{lcccc} 
Variable & VIF & $1 /$ VIF & Chi-square (1) & P-value \\
\hline Regulation & 3.51 & 0.29 & 6.71 & 0.0096 \\
\hline lnAge & 3.34 & 0.30 & & \\
\hline lnSize & 2.75 & 0.36 & & \\
\hline product & 1.08 & 0.92 & & \\
\hline
\end{tabular}

Mean VIF

Independent variables in the hierarchical regression analyses were assessed only if the contribution of the entire set was significant as denoted by the P-values of the F-ratios. The results in Table 2 indicate a significant relationship between regulation and breadth of outreach. The R2 of model 1 with the control variables alone was 0.57 with a significant F-statistic of 27. The t-values for size and age of the MFI as control variables were significant, suggesting that the older and more assets of the MFI, the bigger its number of clients.

The addition of regulation in model 2 increased $\mathrm{R}^{2}$ by close to 7 percent with a significant change in F-statistic of 8.85, implying that 7 percent of the variation in NOAC was explained by regulation. The positive association between regulation and NOAC was confirmed by a coefficient of $\beta=1.63$ (p-value of 0.006), indicating that the number of active clients for the RCBs was statistically higher than that for "susu" companies. The hypothesis that regulation has a positive effect on breadth of outreach was accepted and the alternative hypothesis of no effect rejected.

Table 2. Hierarchical Regression results for regulation and breadth of outreach (NOAC)

\begin{tabular}{lllll}
\hline Variables & $\begin{array}{l}\text { Coefficien } \\
\mathrm{t}\end{array}$ & Robust Std. Error & $t$ & P-value \\
\hline
\end{tabular}

Model 1: Dependent Variable: InNOAC

\begin{tabular}{lllll}
\hline Ln(Age) & 0.53 & 0.25 & 2.11 & $\mathbf{0 . 0 4 0}$ \\
\hline Ln(Size) & 0.36 & 0.16 & 2.23 & $\mathbf{0 . 0 3 0}$ \\
\hline Product & 0.12 & 0.35 & 0.35 & 0.730 \\
\hline constant & 2.31 & 2.01 & 1.15 & 0.256 \\
\hline
\end{tabular}

Model 2: Dependent Variable: InNOAC 


\section{MIN Macrothink}

International Journal of Accounting and Financial Reporting

ISSN 2162-3082 2019, Vol. 9, No. 1

\begin{tabular}{lllll} 
Ln(Age $)$ & 0.17 & 0.22 & 0.76 & 0.448 \\
\hline Ln(Size) & 0.23 & 0.17 & 1.34 & 0.185 \\
\hline product & 0.26 & 0.32 & 0.8 & 0.425 \\
\hline Regulation & 1.63 & 0.57 & 2.86 & $\mathbf{0 . 0 0 6}$ \\
\hline Constant & 4.19 & 2.15 & 1.95 & 0.057 \\
\hline Model & $\mathrm{R}^{2}$ & $\mathrm{~F}(\mathrm{df})(\mathrm{P}-\mathrm{v}$-value $)$ & $\mathrm{R}^{2} \mathrm{Change}$ & $\mathrm{F}(\mathrm{df})$ Change (P-value $)$ \\
\hline 1: & 0.57 & $27.0(3,51)(0.000)$ & & \\
\hline 2: & 0.63 & $24.67(4,50)(0.000)$ & 0.065 & $8.851(1,50)(\mathbf{0 . 0 0 4})$ \\
\hline
\end{tabular}

Hypotheses $2 \mathrm{a}$ and $2 \mathrm{~b}$ sought to assess the relationship between regulation and depth of outreach after controlling for age, size and products of the MFIs. Depth of outreach was measured by the average loan size (ALS) and percentage of women clients (PWC). Equations $2 \mathrm{a}$ and $2 \mathrm{~b}$ above were estimated to test these hypotheses. The results in Tables 3 and 4 , show that regulation had no impact on ALS but had a negative effect on PWC.

As reported in Table 1, there were no multicollinearity problems with the independent variables. The heteroscedasticity test results $(\mathrm{Chi}$-square $=2.01$ and $\mathrm{p}$-value $=0.156)$ indicate that the model was homoscedastic. The first model in the hierarchical regression (Table 3) comprising only the control variables and ALS showed that the control variables explained 22 percent of the variance in ALS and the F-statistic of 4.86 was significant (p-value of 0.005). The addition of the independent variable, regulation, to the model increased R2by 2.5 per-cent and the F-statistic of the change of 1.69 was not significant. The results $(\beta=-0.46$; p-value $=0.20$ ), indicate that regulation had no impact on ALS, implying that there were no differences in ALS between RCBs and "susu" companies. Size of the MFI $(\beta-0.178$, p-value of 0.03 ) and to a lesser extent types of products $(\beta=0.34$, p-value of 0.09$)$ were positively related to ALS, which means the more assets and products of the MFIs the bigger the size of loans to their clients.

Table 3. Hierarchical Regression results for regulation and average loan size

Coefficient Standard Error $\quad \mathrm{t} \quad$ P-value

Model 1: Dependent Variable: InALS

\begin{tabular}{lllll}
\hline Ln(Age) & 0.07 & 0.12 & 0.61 & 0.54 \\
\hline
\end{tabular}




\begin{tabular}{lcccc}
$\operatorname{Ln}($ Size $)$ & 0.14 & 0.07 & 1.95 & 0.06 \\
\hline Product & 0.38 & 0.19 & 1.94 & 0.06 \\
\hline Constant & 5.44 & 0.87 & 6.23 & 0.00 \\
\hline
\end{tabular}

Model 2: Dependent Variable: $\ln A L S$

\begin{tabular}{lllll}
\hline Ln(Age) & 0.17 & 0.14 & 1.23 & 0.23 \\
\hline Ln(Size) & 0.18 & 0.08 & 2.31 & $\mathbf{0 . 0 3}$ \\
\hline Product & 0.34 & 0.19 & 1.72 & $\mathbf{0 . 0 9}$ \\
\hline Regulation & -0.46 & 0.35 & -1.30 & 0.20 \\
\hline Constant & 4.91 & 0.96 & 5.12 & 0.00 \\
\hline Model & $\mathrm{R}^{2}$ & $\mathrm{~F}(\mathrm{df})(\mathrm{P}-\mathrm{value})$ & $\mathrm{R}^{2} \mathrm{Change}$ & $\mathrm{F}(\mathrm{df})$ Change P-Value \\
\hline 1: & 0.222 & $4.856(3,51)(0.005)$ & & \\
\hline 2: & 0.248 & $4.115(4,50)(0.006)$ & 0.25 & $1.692(1,50)(0.199)$ \\
\hline
\end{tabular}

The impact of regulation on percentage of women clients of the MFIs was tested with age, size and product as control variables. The results from the Breuch-Pegan test (Chi-square = 1.51 and $p$-value $=0.219$ ) indicate that the model was free from heteroscedasticity.

Table 4. Hierarchical Regression results for regulation and percentage of women clients
Coefficient Standard Error
t P-value

Model 1: Dependent Variable: InPWC

\begin{tabular}{lllll}
\hline Ln(Age) & -0.02 & 0.02 & -0.98 & 0.33 \\
\hline Ln(Size) & -0.01 & 0.01 & -0.37 & 0.71 \\
\hline Product & 0.01 & 0.02 & 0.07 & 0.95 \\
\hline Constant & 4.22 & 0.11 & 40.09 & 0.00 \\
\hline
\end{tabular}


Model 2: Dependent Variable: InPWC

\begin{tabular}{lllll}
\hline Ln(Age) & 0.01 & 0.02 & 0.29 & 0.77 \\
\hline Ln(Size) & 0.01 & 0.01 & 0.45 & 0.65 \\
\hline Product & -0.01 & 0.02 & -0.25 & 0.80 \\
\hline Regulation & -0.09 & 0.04 & -2.09 & 0.04 \\
\hline Constant & 4.12 & 0.11 & 36.55 & 0.00 \\
\hline Model & $\mathrm{R}^{2}$ & $\mathrm{~F}(\mathrm{df})(\mathrm{P}-\mathrm{value})$ & $\mathrm{R}^{2} \mathrm{Change}$ & $\mathrm{F}(\mathrm{df})$ Change (P-value $)$ \\
\hline $1:$ & 0.071 & $1.31(3,51)(0.282)$ & & \\
\hline $2:$ & 0.146 & $2.13(4,50)(0.091)$ & 0.063 & $4.35(1,50)(0.042)$ \\
\hline
\end{tabular}

The control variables explained 7 per-cent of the variance in PWC and the F-statistic of 1.307 was not significant (Table 4). However, the addition of regulation to the model resulted in a 6.3 per-cent increase in variance explained and the associated change in F-statistic of 4.35 was significant resulting in a negative association between regulation and $\operatorname{PWC}(\beta=-0.087$, p-value $=0.04$ ). The results indicate that RCBs provided loans to fewer women than "susu" companies. Hypothesis $2 \mathrm{~b}$ was therefore supported since regulation was negatively related to PWC as a measure of depth of outreach.

\subsection{Results From the Qualitative Study}

As discussed in section 4, deductive thematic analysis was used in analyzing the qualitative data. It involves six stages of coding and analysis. In the first stage of the analysis codebooks were created a-priori, based on the research questions and the theoretical framework. The codes relating to the effects of regulation on outreach are in Table 5.

Table 5. A-priori codes developed for the research questions - regulation and outreach

Theory-driven codes $\quad$ Explanation of codes

Effect of Regulation on Outreach

- $\quad$ Positive effect

Increase in regulatory activities leads to an increase in outreach

- Negative effect

Increase in regulatory activities leads to a 
decrease in outreach

Regulation has no effect on outreach

The second phase of the analysis involves testing reliability of the codes. It is important to test the applicability of the code to the raw data at this stage. This was done by using a small portion of the transcribed raw data as a test piece. The predetermined codes were used to code the transcribed raw data. An academic staff member of the business school where I am employed as a lecturer was also invited to test the coding. The results were similar and so the a-priori codes were maintained. The applicability and reliability of the codes were assured through this process. In the third stage, I familiarized myself with the raw data by listening to and noting down initial ideas and searching for meanings and patterns within the data. I then transcribed the data and read and re-read the transcripts for accuracy and completeness of the information. This process enhanced reliability as it enabled identification of inconsistencies in the data (Braun and Clarke, 2006; Miles and Huberman, 1994).

The fourth stage required that I identify meaningful units of text that are consistent with the template of codes developed in the code manual (Fereday and Muir-cochrane, 2006). Through an interactive process the codes were matched with corresponding extracts from the data. In the fifth stage, I connected the codes to identify themes and discover patterns in the data. I then organized (clustered) the themes according to the research questions (Braun and Clarke, 2006). In the last stage of the analysis I corroborated and legitimated the coded themes. Corroborating describes the process of confirming the findings (Crabtree and Miller, 1999) and involves further clustering of the themes (if possible) identified previously. Through the interactions of the codes, categories and themes, I scrutinized the previous five stages to ensure the clustered themes are representative of the initial data and the assigned codes (Fereday and Muir-cochrane, 2006). The themes and sub-themes discovered are presented in Table 6.

Table 6. Participant responses to the effect of regulation on outreach

\begin{tabular}{llll}
\hline Themes & Sub-themes & Susu Companies & RCBs \\
\hline $\begin{array}{l}\text { Effect of } \\
\text { regulation } \\
\text { on breadth } \\
\text { of outreach } \\
\text { of MFIs }\end{array}$ & $\begin{array}{l}\text { Positive } \\
\text { effect }\end{array}$ & $\begin{array}{l}\text { "Regulation helps us to "Regulation helps us to reach } \\
\text { increase our outreach }- \text { out to more people since we } \\
\text { clients have confidence in now have access to deposits" } \\
\text { us" }(19,95 \%)\end{array}$ \\
\cline { 2 - 4 } & $\begin{array}{l}\text { Negative } \\
\text { effect }\end{array}$ & \\
\cline { 2 - 4 } & No effect & $\begin{array}{l}\text { "I don't think there is much } \\
\text { relationship between } \\
\text { regulation and outreach" }(1,\end{array}$ \\
\hline
\end{tabular}


$5 \%)$

$\begin{array}{ll}\begin{array}{l}\text { Effect of } \\ \text { regulation } \\ \text { on depth of } \\ \text { outreach }\end{array} & \\ & \end{array}$

"We still engage in group loans so that percentage of our women clients is increased because of regulation" (2, $15.4 \%)$

\begin{tabular}{|c|c|c|c|}
\hline \multirow[t]{2}{*}{$\begin{array}{l}\text { Percent of } \\
\text { Women } \\
\text { Borrowers }\end{array}$} & $\begin{array}{l}\text { Negative } \\
\text { effect }\end{array}$ & $\begin{array}{l}\text { "Regulatory activities could } \\
\text { lead to a fall in the } \\
\text { percentage of women } \\
\text { borrowers" }(17,85 \%)\end{array}$ & $\begin{array}{l}\text { "Percentage of women } \\
\text { borrowers may fall because of } \\
\text { regulations" }(10,76.9 \%)\end{array}$ \\
\hline & No effect & $\begin{array}{l}\text { "Not sure of the influence of } \\
\text { regulation on our women } \\
\text { clients" }(3,15 \%)\end{array}$ & \\
\hline \multirow[t]{4}{*}{$\begin{array}{l}\text { Average } \\
\text { Loan Size }\end{array}$} & & $\begin{array}{l}\text { "Our average loan size } \\
\text { ranges from } 1000 \text { to } 1500 \\
\text { Ghana cedis" }(8,40 \%)\end{array}$ & $\begin{array}{l}\text { "the loan size mostly given to } \\
\text { our clients is } 2000 \text { Ghana cedis" } \\
(2,15.4 \%)\end{array}$ \\
\hline & & $\begin{array}{l}\text { "Our average loan size is } \\
2000 \text { Ghana cedis" (10, } \\
50 \%)\end{array}$ & $\begin{array}{l}\text { "Our average loan size is about } \\
3000 \text { Ghana cedis" }(5,38.5 \%)\end{array}$ \\
\hline & & $\begin{array}{l}\text { "Our average loan size } 4000 \\
\text { Ghana cedis" }(1,5 \%)\end{array}$ & $\begin{array}{l}\text { "our average loan size is } 4000 \\
\text { Ghana cedis" }(4,31 \%)\end{array}$ \\
\hline & & $\begin{array}{l}\text { "our average loan size is } \\
5000 \text { Ghana cedis" }(1,5 \%)\end{array}$ & $\begin{array}{l}\text { "our average loan size is } 5000 \\
\text { Ghana cedis" }(1,7.7 \%)\end{array}$ \\
\hline
\end{tabular}

*The number and percentage of participants mentioning the response are in parentheses.

The comments from the interview participants indicate that regulatory activities increase number of active clients (breadth of outreach) because they improve clients' confidence in the regulated MFI and their sense of security about depositing their monies with the MFIs. Access to deposits then enables MFIs to reach out to more clients with their products and services. This position supports findings from the quantitative analyses that regulation is positively related to breadth of outreach.

In explaining how regulation affects depth of outreach, the interview participants noted that regulatory activities could reduce the percentage of women borrowers who form the majority of the poor. This is because the social responsibility factor which drives MFIs to serve more women would give way to emphasis on sustainability and profitability. This view of the 
participants confirms the quantitative research findings which showed a negative association between regulation and the percentage of women borrowers.

\section{Discussion and Conclusions}

Hypothesis 1 predicted that regulation has a positive effect on breadth of outreach. The results from the quantitative analysis showed a positive association between regulation and number of active clients, the measure of breadth of outreach. This was supported by the qualitative data which revealed that regulatory activities invariably enhanced confidence in MFIs and enabled access to voluntary deposits for on-lending to clients. Regulations therefore, helped the MFIs to reach out to more clients. The findings confirm that of Nyanzu and Peprah (2016) and Mawumba (2012, cited in Nyanzu and Peprah, 2016) whose findings revealed that regulation help to improve the outreach of MFIs.

The "susu" companies admitted that clients were generally hesitant about transacting with them due to their tarnished reputation. Some of these MFIs had taken money from and promised large unsustainable loans to their clients but had eventually declared bankruptcy, leaving their clients with significant losses. Confidence in the informal MFIs had dwindled whilst customers felt more secured about deposits with the formal MFIs.

The findings are however, contrary to those of Hartarska and Nadolnyak (2007) who reported that regulation does not directly affect performance in terms of outreach. Nevertheless, they suggested an indirect benefit from regulation, explaining that it enables MFIs to collect savings from clients, thereby enhancing their ability to reach out to more clients.

The results for hypotheses $2 \mathrm{a}$ and $2 \mathrm{~b}$ showed no effect of regulation on average loan size, but that regulatory involvement could reduce the percentage of women clients. These findings were confirmed by results from the qualitative research which also revealed that regulatory activities could reduce the percentage of women clients who form the majority of the poor. Compliance with regulation adds to the cost of operations so that MFIs that aim at remaining profitable would focus on clients who would pay for the cost of services provided. Women are among the poor who often demand small loans which are costly to administer, therefore loans to women clients may be sacrificed for loans to wealthier clients as regulation increases. The findings agree with that of Nyanzu and Peprah (2016) whose study showed that regulation can result in the marginalization of the poor in order to serve wealthier clients to cover up additional cost associated with regulation. Additionally, many MFIs lend to borrowers organized as groups as well as to individuals. Group lending was promulgated as enhancing repayment rates, due to its associated features of joint-liability, and access to information about members for effective screening, monitoring of repayment, and imposition of social sanctions on members who default (Remenyi, 2000; Bakshi, 2008; Giné and Karlan, 2011; Ghatak, 1999; Satgar, 2003). Nonetheless, MFIs report that these benefits have dwindled over time, so that individual lending is now preferred to group lending.

Regulation enabled increase in outreach because it allowed MFIs access to voluntary savings. In view of this, the initiative by the Bank of Ghana to regulate the activities of the microfinance industry is a step in the right direction. Effective supervision should be carried 
out by the regulator to ensure that MFIs conduct their businesses on sound operating principles. This in turn would help improve their performance and consequently promote viable and sustainable systems of microfinance in Ghana.

In their quest to remain profitable (sustainable), the study revealed that formal MFIs could reduce outreach to women, the poor and under-privileged clients who are costly to reach and to service. This is a deviation from the original objective of MFIs that sought to reach the poor with financial services with the aim of helping to alleviate poverty. The government could support the microfinance industry to continue to fulfill this objective by setting up a loanable fund for the underprivileged and deprived in society that could be accessed by the well-performing MFIs for their poor clients. Such a fund should be controlled by the Bank of Ghana with the mandate to make it available to well-structured and well-performing MFIs at competitive rates. The desire to access such a fund would compel non-performing MFIs to work hard and meet the requirements for access. Alternatively the government could guarantee loans to the poorer segments of society who are able to demonstrate ability to repay.

Care should be taken in generalizing the findings from this study which is based on small samples of MFIs in Ghana. Future research could replicate this study in other Sub-Saharan African countries where research on microfinance is limited. A further limitation of the study is its restriction to investigating the effect of regulations on outreach. Future research could explain the effect of regulations on other performance outcomes such as sustainability of MFIs and their ability to make an impact on their clients' businesses. Finally, the self-regulated MFIs were limited to "susu" companies as credit unions and FNGOs were not readily accessible. Future research could target these semi-formal MFIs.

\section{References}

Adjei, J. K. (2010). Microfinance and Poverty Reduction. The Experience of Ghana. BOLD Communications Limited.

Alabi, J., Alabi, G., \& Ahiawodzi, A. (2007). Effects of "Susu"- a Traditional Micro-Finance Mechanism on Organized and Unorganized Micro and Small Enterprises (MSEs) in Ghana. African Journal of Business Management, 1, 201-208.

Armendariz de Aghion, B., \&Morduch, J. (2005). The Economics of Microfinance. Cambridge: MIT Press.

Arun, T. (2005). Regulating for Development: the Case of Microfinance. Quarterly Journal of Economics and Finance, 45, 346-357.

Aryeetey, E. (1995). Filling the Nich: Informal Finance in Africa, Vol. 34, pp. 26-31. Nairobi: AERC/East African Educational Publishers.

Bakshi, A. R. H. K. (2008). From 'No Collateral No Loan 'to' No Collateral No Default': The Economics of Group Lending Microfinance. The Social Sciences, 3, 611-625. 
Bank of Ghana (BoG). (2011). Legal and Regulatory Framework. Retrieved from http://www.bog.gov.gh/index.php?option=com_content\&view=article\&id=62\&Itemid=122

Bhatt, N., \& Tang, S. Y. (2001). Delivering Microfinance in Developing Countries: Controversies and Policy Perspectives. Policy Studies Journal, 29, 319-333.

Boapeah, O. A. (2011). Assessing the Effectiveness of ARB - Apex Bank Programmes on the Operations of Rural and Community Banks in Ghana. A case study of ARB - Apex Bank, Ashanti Regional Office. A Master's Thesis, Institute of Distant Learning, Kwame Nkrumah University of Science and Technology.

Bouman, F. J. A. (1990). Small, Short and Unsecured: Informal Rural Finance in India. Delhi: Oxford University Press.

Bouman, F. J. A. (1995). Rotating and Accumulating Savings and Credit Association: A Development Perspective. World Development, 23, 371-384.

Bryman, A. (2008). Social Research Methods (3rd ed.). Oxford University Press.

Chord. (2000). Inventory of Ghanaian Micro-Finance Best Practices. Report for Ministry of Finance: Non-Banking Financial Institutions Project. Accra.

Christen, R. P., Lyman, T. R., \& Rosenberg, R. (2003). Guiding Principles on Regulation and Supervision of Microfinance. Microfinance Consensus Guidelines. Washington: CGAP.

Congo, Y. (2002). Performance of microfinance institutions in Burkina Faso' (No. 2002/01). WIDER Discussion Papers, World Institute for Development Economics (UNU-WIDER).

Cull, R., Demirgüç-Kunt, A., \& Morduch, J. (2007). Financial Performance and Outreach: a Global Analysis of Leading Microbanks. The Economic Journal, 117, F107-F133.

Cull, R., Demirgüç-Kunt, A., \& Morduch, J. (2011). Does regulatory supervision curtail microfinance profitability and outreach?. World Development, 39, 949-965.

DeCrombrugghe, A., Tenikue, M., \& Sureda, J. (2008).Performance analysis for a sample of microfinance institutions in India. Annals of Public and Cooperative Economics, 79, 269-299.

Dunford, C. (2001). Building Better Lives: Sustainable Integration of Microfinance with Education in Health, Family Planning, and HIV/AIDS Prevention for the Poorest Entrepreneurs. Journal of Microfinance, 3, 1-25.

Ferro-Luzzi, G., \& Weber, S. (2006). Measuring the performance of microfinance institutions. Retrieved from http://ssrn.com/abstract $=918750$

Fiebig, M., Hannig, A., \& Wisniwski, S. (1999). Savings in the context of microfinance-state of knowledge. Eschborn, Germany: CGAP Working Group on Savings Mobilization/GTZ/BMZ.

Gallardo, J. (2002). A Framework for Regulating Microfinance Institutions: The Experience in Ghana and the Philippines. Policy Research Working Paper No. 2755, The Financial Sector Development Department, The World Bank. 
Ghana Cooperative Credit Union Association (CUA) Ltd. (2012, May22-26). 17th CUA Educational and Biennial Conference Report.

Ghana Cooperative Susu Collectors Association (GCSCA). (2007). Self-Regulation Framework for Susu Collectors in Ghana (2007 ed.).

Ghana Microfinance Institutions Network (GHAMFIN). (2008). Performance Monitoring and Bench-markings of Microfinance Institutions in Ghana. Trends in the Industry during the 2000s. Ghana Government, Accra Ghana.

Ghana Microfinance. (n.d.). General Background on Global Microfinance Trends. Retrieved from http://www.mofep.gov.gh/sites/default/files/pages/microfinance_0.pdflast

Ghatak, M. (1999). Group Lending, Local Information and Peer Selection. Journal of Development Economics, 60, 27-50.

Giné, X., \& Karlan, D. (2011). Group versus Individual Liability: Short and Long Term Evidence from Philippine Microcredit Lending Groups. Working Paper, Yale Univ., New Haven, CT.

Gonzalez, A., \& Rosenberg, R. (2006). The State of Microfinance: Outreach, Profitability and Poverty. Presentation at the World Bank Conference on Access to Finance.

Hair, J. S., Anderson, R. E., Tetham, R. L.,\& Black, W. C. (1995). Multivariate Data Analysis (4th ed.). New Jersey: Prentice Hall.

Hartarska, V. (2005). Governance and Performance of Microfinance Institutions in Central and Eastern Europe and the Newly Independent States. World Development, 33, 1627-1643.

Hartarska, V., \& Nadolnyak, D. (2007). Do Regulated Microfinance Institutions Achieve Better Sustainability and Outreach? Cross-Country Evidence. Applied Economics, 39, 1207-1222.

Hasan, M. M., Hassan, K. M., \& Uddin, M. R. (2009). Local Government Investment, Outreach and Sustainability of Microfinance Institutions: A Case Study of BURO, Bangladesh. The Journal of Social, Political, and Economic Studies, 34, 318-346.

Hermes, N., Lensink, R., \&Meesters, A. (2011). Outreach and Efficiency of Microfinance Institutions. World Development, 39, 938-948.

IFAD (International Fund for Agricultural Development). (2008). The Republic of Ghana Rural and Agricultural Finance Program (RAFiP). Rome.

IFAD. (2000, January24-25). The Report of IFAD's Workshop on Rural Poverty. Discussion Summary and Background Thematic Papers, IFAD, Rome.

Johnson, S., \& Rogaly, B. (1997). Microfinance and poverty reduction. Oxfam.

Kar, A. K. (2011). Microfinance Institutions: A Cross-Country Empirical Investigation of Outreach and Sustainability. Journal of Small Business and Entrepreneurship, 24, 427-446. 


\section{$\triangle 1$ Macrothink}

International Journal of Accounting and Financial Reporting

ISSN 2162-3082

2019, Vol. 9, No. 1

Kereta, B. B. (2007). Outreach and Financial Performance Analysis of Microfinance Institutions in Ethiopia. African Economic Conference, United Nations Conference Center, Addis Ababa, Ethiopia.

Koveos, P., \& Randhawa, D. (2004). Financial Services for the Poor: Assessing Microfinance Institutions. Managerial Finance, 30, 70-95.

Ledgerwood, J. (1999). Sustainable Banking with the Poor, Microfinance Handbook: An Institutional and Financial Perspective. Washington DC: The World Bank.

Llewellyn, D. (1999). The Economic Rationale for Financial Regulation. FSA Occasional Paper Series 1. FSA, London.

Maes, J., \& Foose, L. (2006). Microfinance Services for Very Poor People: Promising Approaches from the Field and the US Law's Mandate to Reach Very Poor People: What Strategies are MFIs Developing, and What do they Mean for the Rest of the Field? -A Practitioner Survey. Microcredit Summit Halifax 2006, the SEEP Network Poverty Outreach Working Group.

Navajas, S., Schreiner, M., Meyer, R. L., Gonzalez-Vega, C., \& Rodriguez-Meza, J. (2000). Microcredit and the Poorest of the Poor: Theory and Evidence from Bolivia. World Development, 28, 333-346.

Nyanzu, F., \& Peprah, J. A. (2016). Regulation, Outreach and Sustainability of MFIs in SSA: A Multilevel Analysis. Retrieved from https://mpra.ub.uni-muenchen.de/70865/

Otto, P. E., \& Ashta, A. (2012). Micro-savings and Market Saturation: The Evolution of Diversity in Saving Products. Savings and Development, 36, 109-135.

Pan, Y., \& Jackson, R. T. (2008). Ethnic Difference in the Relationship Between Acute Inflammation and Serum Ferritin in US Adult Males. Epidemiology and Infection, 136, 421-31.

Paxton, J., \& Cuevas, C. (2002). Outreach and Sustainability of Member Based Rural Financial Intermediaries. In M. Zeller, \& R. L. Meyer (Eds.), The Triangle of Microfinance. Financial Sustainability, Outreach, and Impact. Johns Hopkins University Press, Baltimore and London.

Quaye, I., \& Sarbah, A. (2014). Assessing Alternative Sources of Financing for Small \& Medium Scale Enterprises in Ghana, Case Study of Savings and Loans Companies (S\&Ls) in the Greater Accra Region of Ghana. International Journal of Advancements in Research \& Technology, 3, 123-136.

Remenyi, J. (2000). Is There a State of the Art in Microfinance?. In J. Remenyi, \& B. Quinones Jr. (Eds.), Microfinance and Poverty Reduction: Case Studies from Asia and Pacific. London and New York: Pinter Continuum Press.

Robinson, M. (2001). The Microfinance Revolution: Sustainable Finance for the Poor. Washington DC: The World Bank. 
Rogerson, P. A. (2001). Statistical Methods for Geography. London: Sage.

Rosenberg, R. (2009). Measuring Results of Microfinance Institutions: Minimum Indicators that Donors and Investors Should Track - A Technical Guide. CGAP.

Rutherford, S. (2000). The Poor and their Money. London: Department for International Development (DFID).

Satgar, V. (2003). Comparative Study-Cooperative Banks and the Grameen Bank Model. Johannesburg: COPAC.

Saunders, M., Lewis, P., \& Thornhill, A. (2007). Research Methods for Business Students (4th ed.). Prentice Hall, Financial Times.

Schreiner, M. (2002). Aspects of Outreach: A Framework for Discussion of the Social Benefits of Microfinance. Journal of International Development, 14, 591-603.

Steel, W. F., \& Andah, D. O. (2003). Rural and Micro Finance Regulation in Ghana: Implications for Development and Performance of the Industry. Africa Region Working Paper Series No. 49.

Todaro, M. P., \& Smith, S. C. (2003). Economic Development. Boston: Addison Wesley.

Weber, H. (2006). The Global Political Economy of Microfinance and Poverty Reduction: Locating Local 'Livelihoods' in Political Analysis. In J. L. Fernando (Ed.), Microfinance: Perils and Prospects. London and New York: Routledge Taylor and Francis.

White, H. (1980). A Heteroskedasticity-Consistent Covariance Matrix Estimator and a Direct Test for Heteroscedasticity. Econometrica, 48, 817-838.

Wisniwski, S. (1999). Microsavings Compared to Other Sources of Funds. In A. Hannig, \& S. Wisniwski (Eds.), Challenges of Microsavings Mobilization - Concepts and Views from the field. Deutsche Gesellschhaft fur Technische Zasummenarbeit (GTZ) GmbH, Eschborn.

\section{Copyright Disclaimer}

Copyright for this article is retained by the author(s), with first publication rights granted to the journal.

This is an open-access article distributed under the terms and conditions of the Creative Commons Attribution license (http://creativecommons.org/licenses/by/4.0/) 